\title{
KOMPARASI KINERJA FUZZY TIME SERIES DENGAN MODEL RANTAI MARKOV DALAM MERAMALKAN PRODUK DOMESTIK REGIONAL BRUTO BALI
}

\author{
I Made Arya Antara ${ }^{1}$, I Putu Eka N. Kencana ${ }^{\S 2}$, I Komang Gde Sukarsa ${ }^{3}$ \\ ${ }^{1}$ Jurusan Matematika, Fakultas MIPA - Universitas Udayana [Email: genezisdragonoid@gmail.com] \\ 2 Jurusan Matematika, Fakultas MIPA - Universitas Udayana [Email: i.putu.enk@ gmail.com] \\ ${ }^{3}$ Jurusan Matematika, Fakultas MIPA - Universitas Udayana [Email: sukarsakomang@yahoo.com] \\ $\S$ Corresponding Author
}

\begin{abstract}
This paper aimed to elaborates and compares the performance of Fuzzy Time Series (FTS) model with Markov Chain (MC) model in forecasting the Gross Regional Domestic Product (GDRP) of Bali Province. Both methods were considered as forecasting methods in soft modeling domain. The data used was quarterly data of Bali's GDRP for year 1992 through 2013 from Indonesian Bureau of Statistic at Denpasar Office. Inspite of using the original data, rate of change from two consecutive quarters was used to model. From the in-sample forecasting conducted, we got the Average Forecasting Error Rate (AFER) for FTS dan MC models as much as 0,78 percent and 2,74 percent, respectively. Based-on these findings, FTS outperformed MC in in-sample forecasting for GDRP of Bali's data.
\end{abstract}

Keywords: domestic product, fuzzy modeling, in-sample forecasting, Markov chain

\section{PENDAhULUAN}

Badan Pusat Statistik (BPS) mendefinisikan Produk Domestik Regional Bruto (PDRB) sebagai jumlah nilai tambah barang dan jasa yang dihasilkan seluruh unit usaha di suatu daerah [1]. PDRB lazim digunakan sebagai salah satu indikator penting untuk mengetahui perkembangan perekonomian di suatu wilayah.

Sebagai sebuah ukuran, PDRB berperan penting sebagai salah satu masukan pada rancangan program-program pembangunan daerah. Melalui PDRB dan indikator-indikator penyusunnya, para pengambil kebijakan publik dapat merancang rencana dan program-program pembangunan yang lebih terarah dan terfokus pada peningkatan kesejahteraan masyarakat. Mengacu kepada hal ini, maka usaha untuk menduga nilai PDRB dengan merujuk nilai-nilai PDRB historis semakin intensif dilakukan.

Pada umumnya, teknik peramalan yang diaplikasikan untuk menduga PDRB adalah teknik peramalan yang tergolong ke dalam teknik analisis deret waktu klasik. Sebagai misal, Wanayasa et al. menduga PDRB Provinsi Bali atas dasar harga konstan (adhk) tahun 2011 dari data PDRB Bali periode 1991-2010 menggunakan metode pemulus eksponensial Holt-Winter aditif.
Hasil peramalannya menunjukkan nilai Average Forecasting Error Rate (AFER) dari metode ini sebesar 7,13 persen [2].

Pada jenis permasalahan berbeda, Hansun menggunakan FTS untuk meramalkan pergerakan Indeks Harga Saham Gabungan (IHSG) di Bursa Efek Indonesia. Menggunakan persentase laju perubahan IHSG sebagai himpunan semesta bagi proses fuzzifikasi dengan interval awal sebanyak tujuh, ia memperoleh tingkat keakurasian peramalan in-sample dari FTS sebesar 4,78 persen [3].

Riset ini dimotivasi oleh keinginan untuk mengelaborasi kinerja model FTS dan model Rantai Markov dalam meramalkan secara insample PDRB Provinsi Bali pada periode tahun 1992 hingga 2013. Tingkat akurasi ramalan dari masing-masing model selanjutnya dibandingkan untuk menentukan model yang lebih unggul dalam meramalkan PDRB Provinsi Bali.

Bagian-bagian selanjutnya dari tulisan ini disusun mengikuti format berikut: bagian metode penelitian menguraikan jenis data dan tahapan pengembangan model untuk kedua model yang dielaborasi; bagian hasil dan pembahasan menguraikan secara rinci langkah-langkah pengembangan kedua model, hasil ramalan, serta komparasi keakuratan ramalan kedua model; dan ditutup oleh kesimpulan dan rekomendasi riset. 


\section{METODE PENELITIAN}

Sebagai sebuah studi non-experimental, data yang dianalisis merupakan data sekunder dan diperoleh dari BPS Provinsi Bali dalam bentuk data triwulan PDRB Bali adhk tahun 2000 pada periode data yang diramalkan. Mengingat ada dua model yang dikembangkan pada penelitian ini, maka tahapan pengembangan masing-masing model diuraikan terpisah sebagai berikut:

\section{A. Tahapan Pengembangan Model FTS}

Secara umum model FTS yang dibangun merujuk kepada tahapan yang disarankan oleh [4] dengan memodifikasi penentuan jumlah interval awal. Secara rinci, model FTS dibangun mengikuti tahapan berikut:

(a) Menghitung laju perubahan PDRB antardua triwulan yang berturutan. Laju perubahan PDRB $\left(r_{!}\right)$dihitung menggunakan pers. (1):

$$
r_{!}=\frac{(! 3 ! ! !)}{\$ ! ! !} \times 100
$$

(b) Menentukan himpunan semesta $\mathbb{U}$ dengan syarat seluruh $r_{\text {! menjadi anggotanya. Pada }}$ penelitian ini, batas-batas $\mathbb{U}$ didefinisikan sebagai:

$$
\mathbb{U}=\left[\begin{array}{lll}
R_{\sharp} & -d_{!} ; R_{\#} & +d_{!}
\end{array}\right]
$$

Pada pers. (2), $R_{\#} \quad$ dan $R_{\#}$ adalah nilainilai minimum dan maksimum dari $r_{!}$, dan $d_{\text {! }}$ serta $d_{\text {! }}$ merupakan dua konstanta sembarang;

(c) Membagi $\mathbb{U}$ menjadi $n$ buah interval $\mathrm{U}_{1}, \ldots$, $\mathrm{U}_{\mathrm{n}}$ dengan lebar yang sama. Pada penelitian ini nilai $n$ ditentukan menggunakan formula Sturges [5] dalam bentuk pers. (3):

$$
n=1+3,322 \log _{\text {! }}(\mathrm{N})
$$

(d) Menentukan banyaknya $r_{\text {! yang ada pada }}$ interval $\mathrm{U}_{i}, i=1, \ldots, n$. Selanjutnya, $\mathrm{U}_{i}$

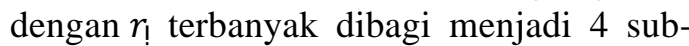
interval; $\mathrm{U}_{i}$ dengan $r_{\text {! }}$ terbanyak kedua dibagi menjadi 3 sub-interval; $\mathrm{U}_{i}$ dengan $r_{!}$terbanyak ketiga dibagi menjadi 2 sub-interval. Interval yang tidak memiliki $r_{\text {! digabungkan }}$ dengan interval sebelumnya yang memiliki anggota. Misalkan jumlah interval akhir yang terbentuk $f$ buah, maka $\mathrm{F}_{1}, \ldots, \mathrm{F}_{f}$ merupakan himpunan variabel-variabel linguistik dalam himpunan fuzzy $\mathbb{F}$ dengan $f_{1}, \ldots, f_{\mathrm{f}}$ menyatakan nilai-nilai linguistik;

(e) Melakukan fuzzifikasi nilai-nilai $r_{\text {! menjadi }}$ nilai-nilai linguistik yang bersesuaian; (f) Melakukan defuzzifikasi variabel linguistik masing-masing amatan sehingga diperoleh nilai $\widehat{r}_{!}$. Defuzzifikasi dilakukan menggunakan fuzzy dengan fungsi keanggotaan segitiga (fuzzy triangular number/FTN) yang dapat dinyatakan dalam pers. (4):

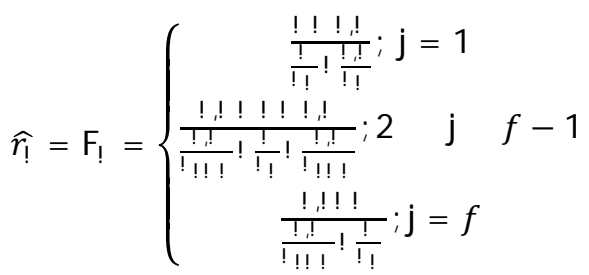

Pada pers. (4), $f_{\mathrm{j}}$ merupakan nilai linguistik dari masing-masing $\mathrm{F}_{\mathrm{j}}$ yang besarnya ditentukan sama dengan nilai tengah interval fuzzy $F_{j}$;

(g) Menduga PDRB pada waktu ke - $t$ menggunakan nilai $\widehat{r_{!}}$yang dihitung pada tahap (f) menggunakan pers. (5):

$$
\widehat{\mathrm{PRB}}_{!}=\left(1+\widehat{r_{t}}\right) \mathrm{PDRB}_{! !} \text {! }
$$

(h) Menghitung galat masing-masing ramalan dan nilai AFER menggunakan pers. (6):

$$
\mathrm{AFER}=\frac{\sum ! \frac{18-! !}{8} !}{!}
$$

\section{B. Tahapan Pengembangan Model Markov}

Tahapan-tahapan awal peramalan PDRB Bali dengan model Markov Chain mengikuti lima tahapan awal model FTS. Perbedaan metode mulai ada pada tahapan ke-enam sebagai berikut [5]:

(f) Menentukan left-hand side (LHS) dan righthand side (RHS) dari masing-masing amatan. LHS dari amatan ke $-i$ merupakan variabel linguistik dari amatan sebelumnya dan RHS-nya merupakan variabel linguistik dari amatan yang bersangkutan;

(g) Menentukan Fuzzy Logical Relationship Group (FLRG), sebuah himpunan yang beranggotakan seluruh relasi dari LHS $\rightarrow$ RHS;

(h) Membuat state transition matrix (STM) berukuran $f \mathrm{x} f$ yang beranggotakan banyaknya amatan pada FLRG: $\mathrm{F}_{\mathrm{i}} \rightarrow \mathrm{F}_{\mathrm{j}}$;

(i) Menghitung transition probability matrix (TPM) berukuran $f \times \mathrm{x} f$ dengan elemen pada baris ke- $i$ dan kolom ke-j dihitung dari pers. (7):

$$
\mathrm{p}_{!, !}=\frac{! ! ! !}{\sum_{! ! ! !}^{!} ! ! !}
$$

Pada pers. (7) $c_{!, !}$menyatakan elemen pada baris ke- $i$ dan kolom ke-j dari STM dan $f$ 
menyatakan total variabel linguistik yang terbentuk pada tahap (d);

(j) Menghitung $\widehat{r_{!}}$dari masing-masing amatan yang telah terfuzzifikasi menjadi $\mathrm{F}_{i}$ pada tahapan (e) dengan menggunakan pers. (8):

$$
\widehat{r}_{!}=\left[\begin{array}{lll}
\mathrm{p}_{!, !} & \ldots & \mathrm{p}_{! ! !}
\end{array}\right]\left[\begin{array}{c}
m_{!} \\
\ldots \\
m_{!}
\end{array}\right]
$$

Pada pers. (8) $m_{!}, \ldots, m_{!}$masing-masing menyatakan nilai tengah dari interval-interval fuzzy $F_{1}, \ldots, F_{f}$;

(k) Menduga nilai ramalan PDRB pada waktu ke- $t$ dengan menggunakan pers. (5);

(1) Menghitung nilai galat ramalan dan AFER dari metode Markov Chain menggunakan pers. (6).

\section{HASIL PENELITIAN DAN DISKUSI}

Lima tahapan awal aktivitas peramalan PDRB Provinsi Bali menggunakan FTS dan MC sama. Memperhatikan hal ini, maka hasil penelitian diuraikan dengan urutan berikut:

\section{A. Penentuan Interval Awal dan Densitas dari Setiap Interval}

Laju perubahan nilai PDRB dari dua triwulan yang berturutan dihitung terlebih dahulu. Jumlah amatan $r_{\text {! }}$ adalah 87 data, dengan $\mathrm{R}_{\mathrm{Min}}$ dan $\mathrm{R}_{\mathrm{Max}}$ masing-masing bernilai $-9,48$ persen dan 34,59 persen. Melalui penetapan $d_{1}$ dan $d_{2}$ masingmasing sebesar 0,52 persen dan 0,41 persen diperoleh $\mathbb{U}=[-10,00 \% ; 35,00 \%]$ sehingga lebar interval $\mathbb{U}=45 \%$. Aplikasi pers. (3) pada penentuan jumlah interval awal memberikan hasil terdapat 8 interval yang harus didefinisikan agar seluruh $r_{\text {! }}$ terklasifikasikan. Delapan interval awal dan jumlah amatan yang berada di dalamnya dicantumkan pada Tabel 1:

Tabel 1. Interval Awal Fuzzy dan Kepadatannya

\begin{tabular}{crrr}
\hline Interval & Batas Kiri & $\begin{array}{r}\text { Batas } \\
\text { Kanan }\end{array}$ & $\begin{array}{r}\text { Frekuensi } \\
\text { Data }\end{array}$ \\
\hline $\mathrm{U}_{1}$ & $-10,00 \%$ & $-4,38 \%$ & 1 \\
\hline $\mathrm{U}_{2}$ & $-4,38 \%$ & $1,25 \%$ & 20 \\
\hline $\mathrm{U}_{3}$ & $1,25 \%$ & $6,88 \%$ & 57 \\
\hline $\mathrm{U}_{4}$ & $6,88 \%$ & $12,50 \%$ & 6 \\
\hline $\mathrm{U}_{5}$ & $12,50 \%$ & $18,13 \%$ & 1 \\
\hline $\mathrm{U}_{6}$ & $18,13 \%$ & $23,75 \%$ & 0 \\
\hline $\mathrm{U}_{7}$ & $23,75 \%$ & $29,38 \%$ & 1 \\
\hline $\mathrm{U}_{8}$ & $29,38 \%$ & $35,00 \%$ & 1 \\
\hline
\end{tabular}

Sumber: Analisis Data (2014)

\section{B. Penentuan Interval Akhir dan Densitas dari Setiap Interval}

Merujuk kepada tahapan yang disarankan oleh [4] dengan memodifikasi penentuan jumlah interval awal], maka $\mathrm{U}_{3}, \mathrm{U}_{2}$, dan $\mathrm{U}_{4}$ sebagai interval-interval dengan frekuensi data tertinggi harus dipecah menjadi sub-sub interval masingmasing berjumlah 4,3 , dan 2 sub interval. Sebaliknya, $\mathrm{U}_{6}$ dengan nilai densitas 0 digabungkan dengan $U_{5}$. Tabel 2 menunjukkan interval akhir yang terbentuk mengikuti kriteria tersebut:

Tabel 2. Interval Akhir Fuzzy dan Nilai Linguistik

\begin{tabular}{crrrr}
\hline $\begin{array}{c}\text { Interval } \\
\text { Fuzzy }\end{array}$ & $\begin{array}{r}\text { Mini- } \\
\text { mum }\end{array}$ & $\begin{array}{r}\text { Nilai } \\
\text { Tengah }\end{array}$ & $\begin{array}{r}\text { Maksi- } \\
\text { mum }\end{array}$ & $\begin{array}{r}\text { Nilai } \\
\text { Lingu- } \\
\text { istik }\end{array}$ \\
\hline $\mathrm{F}_{1}$ & $-10.00 \%$ & $-7.19 \%$ & $-4.38 \%$ & $f_{1}$ \\
\hline $\mathrm{F}_{2}$ & $-4.38 \%$ & $-3.44 \%$ & $-2.50 \%$ & $f_{2}$ \\
\hline $\mathrm{F}_{3}$ & $-2.50 \%$ & $-1.56 \%$ & $-0.63 \%$ & $f_{3}$ \\
\hline $\mathrm{F}_{4}$ & $-0.63 \%$ & $0.31 \%$ & $1.25 \%$ & $f_{4}$ \\
\hline $\mathrm{F}_{5}$ & $1.25 \%$ & $1.95 \%$ & $2.66 \%$ & $f_{5}$ \\
\hline $\mathrm{F}_{6}$ & $2.66 \%$ & $3.36 \%$ & $4.06 \%$ & $f_{6}$ \\
\hline $\mathrm{F}_{7}$ & $4.06 \%$ & $4.77 \%$ & $5.47 \%$ & $f_{7}$ \\
\hline $\mathrm{F}_{8}$ & $5.47 \%$ & $6.17 \%$ & $6.88 \%$ & $f_{8}$ \\
\hline $\mathrm{F}_{9}$ & $6.88 \%$ & $8.28 \%$ & $9.69 \%$ & $f_{9}$ \\
\hline $\mathrm{F}_{10}$ & $9.69 \%$ & $11.09 \%$ & $12.50 \%$ & $f_{10}$ \\
\hline $\mathrm{F}_{11}$ & $12.50 \%$ & $18.13 \%$ & $23.75 \%$ & $f_{11}$ \\
\hline $\mathrm{F}_{12}$ & $23.75 \%$ & $26.56 \%$ & $29.38 \%$ & $f_{12}$ \\
\hline $\mathrm{F}_{13}$ & $29.38 \%$ & $32.19 \%$ & $35.00 \%$ & $f_{13}$ \\
\hline
\end{tabular}

Sumber: Analisis Data (2014)

\section{Fuzzifikasi dan Proses Peramalan FTS}

Informasi pada Tabel 2 selanjutnya digunakan untuk melakukan fuzzifikasi masing-masing $r_{!}$dengan hasil akhir fuzzifikasi tercantum pada lampiran 2. Mengacu kepada representasi fuzzy masing-masing $r_{!}$, maka menggunakan pers. (4), nilai $r_{\text {! }}$ diduga. Sebagai contoh, laju perubahan PDRB pada triwulan III tahun 1992 dengan nilai sebesar 3,05 persen terfuzzifikasi ke dalam variabel linguistik $F_{6}$. Menggunakan pers. (4) nilai ini diramalkan sebesar:

$$
\begin{aligned}
\widehat{r}_{!} & =F_{!}=\frac{0,5+1+0,5}{\frac{0,5}{f_{!}}+\frac{1}{f_{!}}+\frac{0,5}{f_{!}}} \\
& =\frac{\frac{2}{0,5}+\frac{1}{3,36 \%}+\frac{0,5}{4,77 \%}}{} \\
& =3,04 \%
\end{aligned}
$$

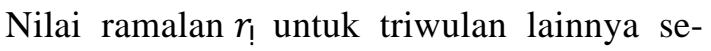
lengkapnya dapat diacu pada lampiran. 


\section{Penghitungan AFER dari Model FTS}

Nilai AFER dari ramalan dengan menggunakan model FTS diperoleh dengan terlebih dulu menduga nilai PDRB dari masing-masing amatan melalui aplikasi pers. (5). Penghitungan akhir menunjukkan AFER peramalan dari model FTS secara in-sample pada data PDRB Provinsi Bali sebesar 0,78 persen. Penghitungan selengkapnya dicantumkan pada lampiran.

\section{E. Peramalan dengan Model Rantai Markov}

Model kedua yang digunakan meramalkan data PDRB Provinsi Bali adalah model Rantai Markov (Markov Chain/MC model). Peramalan diawali dengan membangun FLRG dari representasi fuzzy masing-masing nilai $r_{!}$. FLRG selengkapnya dicantumkan pada lampiran. Merujuk kepada FLRG yang terbentuk, dibangun state transition diagram seperti gambar 1 dengan STM ditunjukkan di bawahnya:

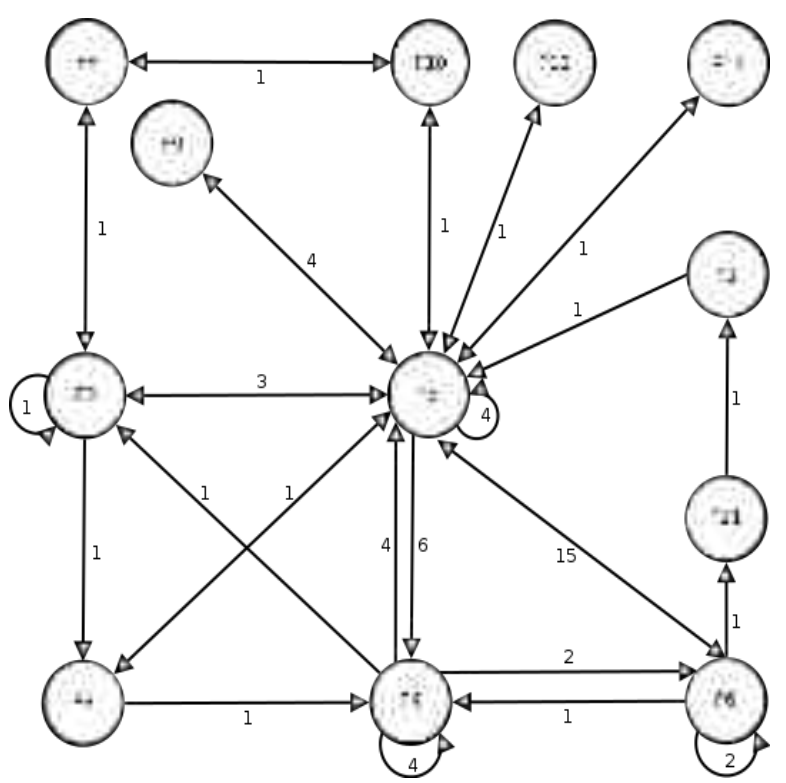

Gambar 1. Diagram Transisi Markov

$$
\mathrm{STM}=\left(\begin{array}{ccccccccccccc} 
& F_{1} & F_{2} & F_{3} & F_{4} & F_{5} & F_{6} & F_{8} & F_{9} & F_{10} & F_{11} & F_{12} & F_{13} \\
F_{1} & & & & & 1 & & & & & & & \\
F_{2} & 1 & 1 & & 3 & & 1 & & & & & \\
F_{3} & & & 1 & 1 & & & & & & & \\
F_{4} & 1 & & 4 & 4 & 2 & & & & & & \\
F_{5} & 3 & 1 & 6 & 4 & 15 & & 4 & 1 & & 1 & 1 \\
F_{6} & & & & 1 & 15 & 2 & & & 1 & & \\
F_{8} & & 1 & & & & & & & 1 & & & \\
F_{9} & & & & & 4 & & & & & & \\
F_{10} & & & & & 1 & & 1 & & & & & \\
F_{11} & 1 & & & & & & & & & & & \\
F_{12} & & & & & 1 & & & & & & \\
F_{13} & & & & & 1 & & & & & &
\end{array}\right)
$$

Pada gambar 1, awal dan akhir dari simbolsimbol panah merupakan LHS dan RHS dari FLRG yang terbentuk dan angka-angka menunjukkan jumlah dari LHS $\rightarrow$ RHS pada masing-masing relasi. Mengacu kepada gambar 1, maka STM disusun dengan baris dan kolom merupakan representasi dari LHS dan RHS. Pada STM, unsur yang kosong menunjukkan tidak ada amatan dengan LHS menuju RHS yang bersesuaian.

Mengacu kepada STM yang dibangun, maka perlu disusun matriks peluang transisi (TPM) Markov yang digunakan untuk menduga nilai $r_{!}$. Berikut adalah TPM yang disusun dari STM sebelumnya:

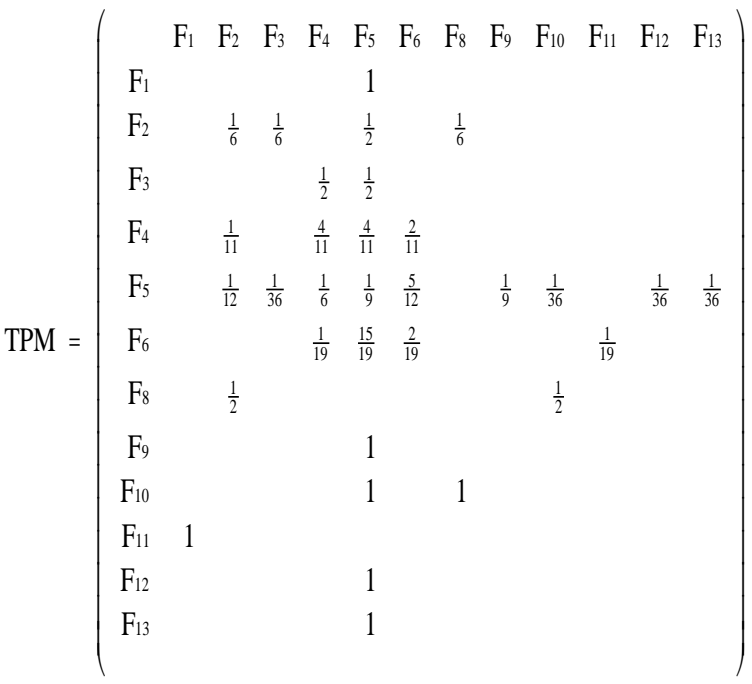

Nilai pada elemen-elemen TPM selanjutnya digunakan untuk menduga nilai $r_{\text {! }}$ setiap amatan sesuai dengan FLRG-nya. Sebagai contoh, laju perubahan PDRB pada triwulan III tahun 1992 dengan nilai sebesar 3,05 persen diduga dengan mengamati bahwa nilai LHS dari amatan ini adalah $\mathrm{F}_{5}$. Pada TPM terlihat ada sembilan kemungkinan state RHS bila LHS $=\mathrm{F}_{5}$, masingmasing dengan peluang yang berbeda. Nilai $r_{\text {! }}$ pada amatan ini selanjutnya bisa diduga sebagai jumlah hasil perkalian (sumproduct) dari peluang state berikutnya bila LHS $=\mathrm{F}_{5}$ dengan nilai-nilai tengah dari seluruh interval fuzzy (lihat pers. 8), sebagai berikut:

$$
\widehat{r}_{!}=\left(\begin{array}{lll}
0 & \ldots & \frac{1}{36}
\end{array}\right)\left(\begin{array}{c}
-7,19 \% \\
\vdots \\
32,19 \%
\end{array}\right)=4,20 \%
$$

Nilai penduga yang diperoleh selanjutnya digunakan untuk menduga nilai PDRB dari periode yang diramalkan. Menggunakan pers. (5) diperoleh nilai PDRB triwulan III tahun 1992 sebesar 1020439 juta rupiah, dengan persentase galat sebesar 1,12 persen. 
Nilai AFER model Rantai Markov diperoleh dengan menghitung rataan seluruh galat amatan (perhitungan lengkap pada lampiran) sebesar 2,74 persen; lebih besar dari nilai AFER yang diperoleh menggunakan metode FTS. Gambar 2 memperlihatkan histogram data PDRB, dan data hasil ramalan menggunakan kedua model:

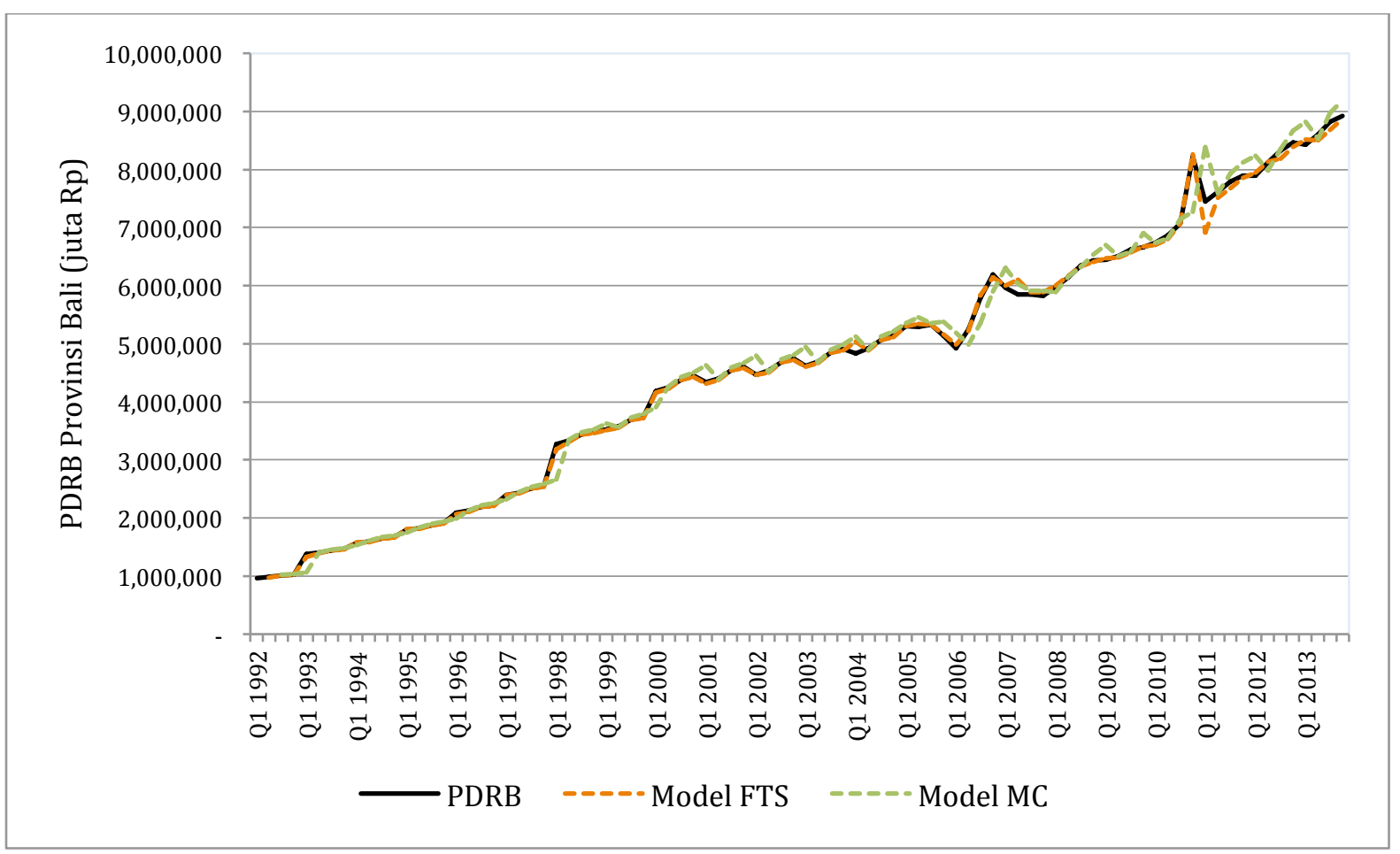

Gambar 2. Grafik Komparasi Data Asli dengan Hasil Peramalan Model FTS dan MC

\section{SIMPULAN DAN REKOMENDASI}

\section{A. Simpulan Penelitian}

Penelitian yang ditujukan untuk mengetahui kinerja model FTS dan Rantai Markov dalam meramalkan PDRB Provinsi Bali pada periode tahun 1992 - 2013 atas dasar harga konstan tahun 2000 menyimpulkan:

1. Kedua model menghasilkan ramalan yang baik ditinjau dari nilai rataan persentase galat (AFER) di bawah lima persen. Nilai-nilai AFER pada model FTS dan Rantai Markov masing-masing sebesar 0,78 persen dan 2,74 persen;

2. Melalui perbandingan kedua nilai AFER tersebut, model FTS dengan AFER yang lebih kecil memiliki tingkat keakurasian ramalan yang lebih baik dibandingkan dengan model Rantai Markov.

\section{B. Rekomendasi}

Meskipun kedua model memberikan nilainilai ramalan dengan batas galat yang masih bisa diterima, beberapa hal direkomendasikan terkait dengan hasil penelitian:

1. Nilai-nilai AFER diperoleh terbatas pada peramalan yang bersifat in-sample. Mengacu kepada hal ini, disarankan untuk memeriksa nilai PDRB Provinsi Bali pada tahun 2014 sehingga AFER untuk peramalan yang bersifat out-of-sample bisa dihitung;

2. Disarankan untuk melakukan pemeriksaan pencilan, sebelum dilakukan proses peramalan menggunakan kedua model;

3. Disarankan mencoba parameter-parameter yang berbeda dari fungsi keanggotaan segitiga yang digunakan saat defuzzifikasi.

\section{DAFTAR PUSTAKA}

[1] BPS Provinsi Bali, 2013. Produk Domestik Regional Bruto (PDRB) Provinsi Bali 2008 2012. Denpasar: Badan Pusat Statistik Provinsi Bali.

[2] Wanayasa, IGN. Arya., Kencana, I Putu EN. \& Nilakusmawati, D.P.E., "Peramalan Produk Domestik Regional Bruto (PDRB) Provinsi 
Bali dengan Menggunakan Metode Fuzzy Time Series", E-Jurnal UNUD, 1(1), pp.1219,2012

[3] Seng Hansun, "Peramalan Data IHSG Menggunakan Fuzzy Time Series," IJCCS, vol. 6 (2), pp. 79-88, 2012.

[4] Meredith Stevenson and John E. Porter, "Fuzzy Time Series Forecasting Using Percentage Change as the Universe of Discour- se," World Academy of Science, Engineering and Technology, vol. 55, pp. 154-157, 2009.

[5] R. C. Tsaur, “A Fuzzy Time Series-Markov Chain Model With An Application To Forecast the Exchange Rate Between The Taiwan And US Dollar", International Journal of Innovative Computing, Information and Control, Volume 8, pp. 4931-42, 2012.

\section{LAMPIRAN}

Lampiran. Data PDRB Bali 1992 - 2013 adhk Tahun 2000 (Juta Rp) dan Parameter-parameter pada Model FTS dan Rantai Markov

\begin{tabular}{|c|c|c|c|c|c|c|c|c|c|}
\hline \multirow{2}{*}{ Periode } & \multirow{2}{*}{ PDRB } & \multirow[b]{2}{*}{$r_{\mathrm{t}}$} & \multicolumn{3}{|c|}{ Model FTS } & \multicolumn{4}{|c|}{ Model Markov } \\
\hline & & & $\widehat{r} !$ & $\widehat{\mathrm{PDRB}}_{4}$ & $\%$ Galat & FLRG & $\widehat{r_{!}}$ & $\widehat{P D R B}_{1}$ & $\%$ Galat \\
\hline Q1-1992 & 963504 & & & & & & & & \\
\hline Q2-1992 & 979315 & $1.64 \%$ & $0.88 \%$ & 972027 & $0.74 \%$ & & & & \\
\hline Q3 - 1992 & 1009142 & $3.05 \%$ & $3.04 \%$ & 1009055 & $0.01 \%$ & F5 $\rightarrow$ F6 & $4.20 \%$ & 1020439 & $1.12 \%$ \\
\hline Q4 - 1992 & 1024441 & $1.52 \%$ & $0.88 \%$ & 1018069 & $0.62 \%$ & $\mathrm{~F} 6 \rightarrow \mathrm{F} 5$ & $2.87 \%$ & 1038064 & $1.33 \%$ \\
\hline Q1-1993 & 1378770 & $34.59 \%$ & $30.07 \%$ & 1332442 & $3.36 \%$ & $\mathrm{~F} 5 \rightarrow \mathrm{F} 13$ & $4.20 \%$ & 1067460 & $22.58 \%$ \\
\hline Q2-1993 & 1401395 & $1.64 \%$ & $0.88 \%$ & 1390967 & $0.74 \%$ & $\mathrm{~F} 13 \rightarrow \mathrm{F} 5$ & $1.95 \%$ & 1405699 & $0.31 \%$ \\
\hline Q3 - 1993 & 1444078 & $3.05 \%$ & $3.04 \%$ & 1443952 & $0.01 \%$ & $\mathrm{~F} 5 \rightarrow \mathrm{F} 6$ & $4.20 \%$ & 1460243 & $1.12 \%$ \\
\hline Q4-1993 & 1465970 & $1.52 \%$ & $0.88 \%$ & 1456853 & $0.62 \%$ & $\mathrm{~F} 6 \rightarrow \mathrm{F} 5$ & $2.87 \%$ & 1485465 & $1.33 \%$ \\
\hline Q1-1994 & 1572696 & $7.28 \%$ & $8.10 \%$ & 1584750 & $0.77 \%$ & $\mathrm{~F} 5 \rightarrow \mathrm{F} 9$ & $4.20 \%$ & 1527529 & $2.87 \%$ \\
\hline Q2-1994 & 1598504 & $1.64 \%$ & $0.88 \%$ & 1586609 & $0.74 \%$ & $\mathrm{~F} 9 \rightarrow \mathrm{F} 5$ & $1.95 \%$ & 1603413 & $0.31 \%$ \\
\hline Q3 - 1994 & 1647190 & $3.05 \%$ & $3.04 \%$ & 1647047 & $0.01 \%$ & $\mathrm{~F} 5 \rightarrow \mathrm{F} 6$ & $4.20 \%$ & 1665629 & $1.12 \%$ \\
\hline Q4 - 1994 & 1672161 & $1.52 \%$ & $0.88 \%$ & 1661762 & $0.62 \%$ & $\mathrm{~F} 6 \rightarrow \mathrm{F} 5$ & $2.87 \%$ & 1694398 & $1.33 \%$ \\
\hline Q1-1995 & 1795382 & $7.37 \%$ & $8.10 \%$ & 1807648 & $0.68 \%$ & $\mathrm{~F} 5 \rightarrow \mathrm{F} 9$ & $4.20 \%$ & 1742379 & $2.95 \%$ \\
\hline Q2 - 1995 & 1824843 & $1.64 \%$ & $0.88 \%$ & 1811264 & $0.74 \%$ & $\mathrm{~F} 9 \rightarrow \mathrm{F} 5$ & $1.95 \%$ & 1830448 & $0.31 \%$ \\
\hline Q3-1995 & 1880423 & $3.05 \%$ & $3.04 \%$ & 1880259 & $0.01 \%$ & $\mathrm{~F} 5 \rightarrow \mathrm{F} 6$ & $4.20 \%$ & 1901472 & $1.12 \%$ \\
\hline Q4-1995 & 1908931 & $1.52 \%$ & $0.88 \%$ & 1897058 & $0.62 \%$ & $\mathrm{~F} 6 \rightarrow \mathrm{F} 5$ & $2.87 \%$ & 1934315 & $1.33 \%$ \\
\hline Q1-1996 & 2089027 & $9.43 \%$ & $8.10 \%$ & 2063602 & $1.22 \%$ & $\mathrm{~F} 5 \rightarrow \mathrm{F} 9$ & $4.20 \%$ & 1989091 & $4.78 \%$ \\
\hline Q2-1996 & 2123307 & $1.64 \%$ & $0.88 \%$ & 2107507 & $0.74 \%$ & $\mathrm{~F} 9 \rightarrow \mathrm{F} 5$ & $1.95 \%$ & 2129828 & $0.31 \%$ \\
\hline Q3-1996 & 2187977 & $3.05 \%$ & $3.04 \%$ & 2187787 & $0.01 \%$ & $\mathrm{~F} 5 \rightarrow \mathrm{F} 6$ & $4.20 \%$ & 2212469 & $1.12 \%$ \\
\hline Q4-1996 & 2221147 & $1.52 \%$ & $0.88 \%$ & 2207332 & $0.62 \%$ & $\mathrm{~F} 6 \rightarrow \mathrm{F} 5$ & $2.87 \%$ & 2250683 & $1.33 \%$ \\
\hline Q1 - 1997 & 2398197 & $7.97 \%$ & $8.10 \%$ & 2401115 & $0.12 \%$ & $\mathrm{~F} 5 \rightarrow \mathrm{F} 9$ & $4.20 \%$ & 2314418 & $3.49 \%$ \\
\hline Q2-1997 & 2437550 & $1.64 \%$ & $0.88 \%$ & 2419412 & $0.74 \%$ & $\mathrm{~F} 9 \rightarrow \mathrm{F} 5$ & $1.95 \%$ & 2445037 & $0.31 \%$ \\
\hline Q3 - 1997 & 2511791 & $3.05 \%$ & $3.04 \%$ & 2511573 & $0.01 \%$ & $\mathrm{~F} 5 \rightarrow \mathrm{F} 6$ & $4.20 \%$ & 2539908 & $1.12 \%$ \\
\hline Q4 - 1997 & 2549870 & $1.52 \%$ & $0.88 \%$ & 2534011 & $0.62 \%$ & $\mathrm{~F} 6 \rightarrow \mathrm{F} 5$ & $2.87 \%$ & 2583778 & $1.33 \%$ \\
\hline Q1 - 1998 & 3277421 & $28.53 \%$ & $24.76 \%$ & 3181282 & $2.93 \%$ & $\mathrm{~F} 5 \rightarrow \mathrm{F} 12$ & $4.20 \%$ & 2656945 & $18.93 \%$ \\
\hline Q2-1998 & 3331202 & $1.64 \%$ & $0.88 \%$ & 3306414 & $0.74 \%$ & $\mathrm{~F} 12 \rightarrow \mathrm{F} 5$ & $1.95 \%$ & 3341433 & $0.31 \%$ \\
\hline Q3 - 1998 & 3432661 & $3.05 \%$ & $3.04 \%$ & 3432363 & $0.01 \%$ & $\mathrm{~F} 5 \rightarrow \mathrm{F} 6$ & $4.20 \%$ & 3471086 & $1.12 \%$ \\
\hline Q4-1998 & 3484701 & $1.52 \%$ & $0.88 \%$ & 3463027 & $0.62 \%$ & $\mathrm{~F} 6 \rightarrow \mathrm{F} 5$ & $2.87 \%$ & 3531039 & $1.33 \%$ \\
\hline Q1 - 1999 & 3520936 & $1.04 \%$ & $0.64 \%$ & 3506925 & $0.40 \%$ & $\mathrm{~F} 5 \rightarrow \mathrm{F} 4$ & $4.20 \%$ & 3631031 & $3.13 \%$ \\
\hline Q2-1999 & 3578713 & $1.64 \%$ & $0.88 \%$ & 3552083 & $0.74 \%$ & $\mathrm{~F} 4 \rightarrow \mathrm{F} 5$ & $1.12 \%$ & 3560447 & $0.51 \%$ \\
\hline Q3 - 1999 & 3687711 & $3.05 \%$ & $3.04 \%$ & 3687391 & $0.01 \%$ & $\mathrm{~F} 5 \rightarrow \mathrm{F} 6$ & $4.20 \%$ & 3728991 & $1.12 \%$ \\
\hline Q4 - 1999 & 3743617 & $1.52 \%$ & $0.88 \%$ & 3720334 & $0.62 \%$ & $\mathrm{~F} 6 \rightarrow \mathrm{F} 5$ & $2.87 \%$ & 3793399 & $1.33 \%$ \\
\hline $\mathrm{Q} 1-2000$ & 4184187 & $11.77 \%$ & $11.23 \%$ & 4164002 & $0.48 \%$ & $\mathrm{~F} 5 \rightarrow \mathrm{F} 10$ & $4.20 \%$ & 3900820 & $6.77 \%$ \\
\hline $\mathrm{Q} 2-2000$ & 4252848 & $1.64 \%$ & $0.88 \%$ & 4221201 & $0.74 \%$ & $\mathrm{~F} 10 \rightarrow \mathrm{F} 5$ & $1.95 \%$ & 4265909 & $0.31 \%$ \\
\hline $\mathrm{Q} 3-2000$ & 4382378 & $3.05 \%$ & $3.04 \%$ & 4381998 & $0.01 \%$ & $\mathrm{~F} 5 \rightarrow \mathrm{F} 6$ & $4.20 \%$ & 4431434 & $1.12 \%$ \\
\hline $\mathrm{Q} 4-2000$ & 4448816 & $1.52 \%$ & $0.88 \%$ & 4421146 & $0.62 \%$ & $\mathrm{~F} 6 \rightarrow \mathrm{F} 5$ & $2.87 \%$ & 4507975 & $1.33 \%$ \\
\hline Q1 - 2001 & 4332393 & $-2.62 \%$ & $-2.94 \%$ & 4318060 & $0.33 \%$ & $\mathrm{~F} 5 \rightarrow \mathrm{F} 2$ & $4.20 \%$ & 4635632 & $7.00 \%$ \\
\hline Q2-2001 & 4403485 & $1.64 \%$ & $0.88 \%$ & 4370719 & $0.74 \%$ & $\mathrm{~F} 2 \rightarrow \mathrm{F} 5$ & $1.17 \%$ & 4383163 & $0.46 \%$ \\
\hline Q3-2001 & 4537603 & $3.05 \%$ & $3.04 \%$ & 4537209 & $0.01 \%$ & $\mathrm{~F} 5 \rightarrow \mathrm{F} 6$ & $4.20 \%$ & 4588397 & $1.12 \%$ \\
\hline Q4-2001 & 4606394 & $1.52 \%$ & $0.88 \%$ & 4577744 & $0.62 \%$ & $\mathrm{~F} 6 \rightarrow \mathrm{F} 5$ & $2.87 \%$ & 4667649 & $1.33 \%$ \\
\hline
\end{tabular}




\begin{tabular}{|c|c|c|c|c|c|c|c|c|c|}
\hline \multirow{2}{*}{ Periode } & \multirow{2}{*}{ PDRB } & \multirow[b]{2}{*}{$r_{\mathrm{t}}$} & \multicolumn{3}{|c|}{ Model FTS } & \multicolumn{4}{|c|}{ Model Markov } \\
\hline & & & $\widehat{r}$ & $\mathrm{P}_{\mathrm{DRB}_{1}}$ & $\%$ Galat & FLRG & $\widehat{r_{!}}$ & $\widehat{P}_{\mathrm{DRB}_{!}}$ & $\%$ Galat \\
\hline $\mathrm{Q} 1-2002$ & 4464203 & $-3.09 \%$ & $-2.94 \%$ & 4471006 & $0.15 \%$ & $\mathrm{U} 5 \rightarrow \mathrm{U} 2$ & $4.20 \%$ & 4799827 & $7.52 \%$ \\
\hline Q2-2002 & 4537459 & $1.64 \%$ & $0.88 \%$ & 4503695 & $0.74 \%$ & $\mathrm{U} 2 \rightarrow \mathrm{U} 5$ & $1.17 \%$ & 4516518 & $0.46 \%$ \\
\hline Q3-2002 & 4675658 & $3.05 \%$ & $3.04 \%$ & 4675252 & $0.01 \%$ & $\mathrm{U} 5 \rightarrow \mathrm{U} 6$ & $4.20 \%$ & 4727997 & $1.12 \%$ \\
\hline Q4 - 2002 & 4746541 & $1.52 \%$ & $0.88 \%$ & 4717020 & $0.62 \%$ & $\mathrm{U} 6 \rightarrow \mathrm{U} 5$ & $2.87 \%$ & 4809660 & $1.33 \%$ \\
\hline Q1 - 2003 & 4623407 & $-2.59 \%$ & $-2.94 \%$ & 4607034 & $0.35 \%$ & $\mathrm{U} 5 \rightarrow \mathrm{U} 2$ & $4.20 \%$ & 4945859 & $6.97 \%$ \\
\hline $\mathrm{Q} 2-2003$ & 4699274 & $1.64 \%$ & $0.88 \%$ & 4664307 & $0.74 \%$ & $\mathrm{U} 2 \rightarrow \mathrm{U} 5$ & $1.17 \%$ & 4677588 & $0.46 \%$ \\
\hline Q3-2003 & 4842402 & $3.05 \%$ & $3.04 \%$ & 4841981 & $0.01 \%$ & U5 $\rightarrow$ U6 & $4.20 \%$ & 4896607 & $1.12 \%$ \\
\hline Q4 - 2003 & 4915813 & $1.52 \%$ & $0.88 \%$ & 4885239 & $0.62 \%$ & $\mathrm{U} 6 \rightarrow \mathrm{U} 5$ & $2.87 \%$ & 4981183 & $1.33 \%$ \\
\hline Q1-2004 & 4837204 & $-1.60 \%$ & $2.46 \%$ & 5036514 & $4.12 \%$ & $\mathrm{U} 5 \rightarrow \mathrm{U} 3$ & $4.20 \%$ & 5122239 & $5.89 \%$ \\
\hline $\mathrm{Q} 2-2004$ & 4916580 & $1.64 \%$ & $0.88 \%$ & 4879995 & $0.74 \%$ & $\mathrm{U} 3 \rightarrow \mathrm{U} 5$ & $1.13 \%$ & 4892000 & $0.50 \%$ \\
\hline Q3-2004 & 5066326 & $3.05 \%$ & $3.04 \%$ & 5065886 & $0.01 \%$ & U5 $\rightarrow$ U6 & $4.20 \%$ & 5123038 & $1.12 \%$ \\
\hline Q4 - 2004 & 5143133 & $1.52 \%$ & $0.88 \%$ & 5111144 & $0.62 \%$ & $\mathrm{U} 6 \rightarrow \mathrm{U} 5$ & $2.87 \%$ & 5211525 & $1.33 \%$ \\
\hline Q1-2005 & 5301871 & $3.09 \%$ & $3.04 \%$ & 5299319 & $0.05 \%$ & $\mathrm{U} 5 \rightarrow \mathrm{U} 6$ & $4.20 \%$ & 5359104 & $1.08 \%$ \\
\hline $\mathrm{Q} 2-2005$ & 5289872 & $-0.23 \%$ & $0.64 \%$ & 5335684 & $0.87 \%$ & $\mathrm{U} 6 \rightarrow \mathrm{U} 4$ & $2.87 \%$ & 5453820 & $3.10 \%$ \\
\hline Q3-2005 & 5325780 & $0.68 \%$ & $0.64 \%$ & 5323608 & $0.04 \%$ & $\mathrm{U} 4 \rightarrow \mathrm{U} 4$ & $1.12 \%$ & 5349233 & $0.44 \%$ \\
\hline $\mathrm{Q} 4-2005$ & 5134990 & $-3.58 \%$ & $-2.94 \%$ & 5169249 & $0.67 \%$ & $\mathrm{U} 4 \rightarrow \mathrm{U} 2$ & $1.12 \%$ & 5385544 & $4.88 \%$ \\
\hline Q1 - 2006 & 4928053 & $-4.03 \%$ & $-2.94 \%$ & 4984066 & $1.14 \%$ & $\mathrm{U} 2 \rightarrow \mathrm{U} 2$ & $1.17 \%$ & 5195166 & $5.42 \%$ \\
\hline Q2-2006 & 5249667 & $6.53 \%$ & $6.11 \%$ & 5229168 & $0.39 \%$ & $\mathrm{U} 2 \rightarrow \mathrm{U} 8$ & $1.17 \%$ & 4985804 & $5.03 \%$ \\
\hline Q3-2006 & 5791603 & $10.32 \%$ & $11.23 \%$ & 5839171 & $0.82 \%$ & $\mathrm{U} 8 \rightarrow \mathrm{U} 10$ & $1.95 \%$ & 5352200 & $7.59 \%$ \\
\hline $\mathrm{Q} 4-2006$ & 6189001 & $6.86 \%$ & $6.11 \%$ & 6145482 & $0.70 \%$ & $\mathrm{U} 10 \rightarrow \mathrm{U} 8$ & $1.95 \%$ & 5904720 & $4.59 \%$ \\
\hline Q1 - 2007 & 5960000 & $-3.70 \%$ & $-2.94 \%$ & 6007098 & $0.79 \%$ & $\mathrm{U} 8 \rightarrow \mathrm{U} 2$ & $1.95 \%$ & 6309880 & $5.87 \%$ \\
\hline Q2-2007 & 5850000 & $-1.85 \%$ & $2.46 \%$ & 6106339 & $4.38 \%$ & $\mathrm{U} 2 \rightarrow \mathrm{U} 3$ & $1.17 \%$ & 6029844 & $3.07 \%$ \\
\hline Q3 - 2007 & 5850000 & $0.00 \%$ & $0.64 \%$ & 5887309 & $0.64 \%$ & $\mathrm{U} 3 \rightarrow \mathrm{U} 4$ & $1.13 \%$ & 5916270 & $1.13 \%$ \\
\hline Q4 - 2007 & 5820000 & $-0.51 \%$ & $0.64 \%$ & 5887309 & $1.16 \%$ & $\mathrm{U} 4 \rightarrow \mathrm{U} 4$ & $1.12 \%$ & 5915646 & $1.64 \%$ \\
\hline Q1 - 2008 & 5980000 & $2.75 \%$ & $3.04 \%$ & 5996741 & $0.28 \%$ & U4 $\rightarrow$ U6 & $1.12 \%$ & 5885310 & $1.58 \%$ \\
\hline Q2-2008 & 6140000 & $2.68 \%$ & $3.04 \%$ & 6161599 & $0.35 \%$ & U6 $\rightarrow$ U6 & $2.87 \%$ & 6151384 & $0.19 \%$ \\
\hline Q3-2008 & 6350000 & $3.42 \%$ & $3.04 \%$ & 6326458 & $0.37 \%$ & U6 $\rightarrow$ U6 & $2.87 \%$ & 6315970 & $0.54 \%$ \\
\hline Q4 - 2008 & 6430000 & $1.26 \%$ & $0.88 \%$ & 6406174 & $0.37 \%$ & $\mathrm{U} 6 \rightarrow \mathrm{U} 5$ & $2.87 \%$ & 6531988 & $1.59 \%$ \\
\hline Q1 - 2009 & 6440000 & $0.16 \%$ & $0.64 \%$ & 6471008 & $0.48 \%$ & $\mathrm{U} 5 \rightarrow \mathrm{U} 4$ & $4.20 \%$ & 6700010 & $4.04 \%$ \\
\hline Q2-2009 & 6510000 & $1.09 \%$ & $0.64 \%$ & 6481071 & $0.44 \%$ & $\mathrm{U} 4 \rightarrow \mathrm{U} 4$ & $1.12 \%$ & 6512267 & $0.03 \%$ \\
\hline Q3-2009 & 6630000 & $1.84 \%$ & $0.88 \%$ & 6567589 & $0.94 \%$ & $\mathrm{U} 4 \rightarrow \mathrm{U} 5$ & $1.12 \%$ & 6583053 & $0.71 \%$ \\
\hline Q4 - 2009 & 6660000 & $0.45 \%$ & $0.64 \%$ & 6672283 & $0.18 \%$ & $\mathrm{U} 5 \rightarrow \mathrm{U} 4$ & $4.20 \%$ & 6908408 & $3.73 \%$ \\
\hline Q1 - 2010 & 6740000 & $1.20 \%$ & $0.64 \%$ & 6702474 & $0.56 \%$ & $\mathrm{U} 4 \rightarrow \mathrm{U} 4$ & $1.12 \%$ & 6734736 & $0.08 \%$ \\
\hline $\mathrm{Q} 2-2010$ & 6860000 & $1.78 \%$ & $0.88 \%$ & 6799624 & $0.88 \%$ & $\mathrm{U} 4 \rightarrow \mathrm{U} 5$ & $1.12 \%$ & 6815634 & $0.65 \%$ \\
\hline Q3-2010 & 7070000 & $3.06 \%$ & $3.04 \%$ & 7068323 & $0.02 \%$ & $\mathrm{U} 5 \rightarrow \mathrm{U} 6$ & $4.20 \%$ & 7148066 & $1.10 \%$ \\
\hline Q4 - 2010 & 8230000 & $16.41 \%$ & $16.80 \%$ & 8257573 & $0.34 \%$ & $\mathrm{U} 6 \rightarrow \mathrm{U} 11$ & $2.87 \%$ & 7272623 & $11.63 \%$ \\
\hline Q1 - 2011 & 7450000 & $-9.48 \%$ & $-15.95 \%$ & 6917540 & $7.15 \%$ & $\mathrm{U} 11 \rightarrow \mathrm{U} 1$ & $1.95 \%$ & 8390742 & $12.63 \%$ \\
\hline Q2 - 2011 & 7610000 & $2.15 \%$ & $0.88 \%$ & 7515905 & $1.24 \%$ & $\mathrm{U} 1 \rightarrow \mathrm{U} 5$ & $1.95 \%$ & 7595508 & $0.19 \%$ \\
\hline Q3-2011 & 7790000 & $2.37 \%$ & $0.88 \%$ & 7677320 & $1.45 \%$ & U5 $\rightarrow$ U5 & $4.20 \%$ & 7929561 & $1.79 \%$ \\
\hline Q4 - 2011 & 7900000 & $1.41 \%$ & $0.88 \%$ & 7858913 & $0.52 \%$ & U5 $\rightarrow$ U5 & $4.20 \%$ & 8117119 & $2.75 \%$ \\
\hline Q1 - 2012 & 7900000 & $0.00 \%$ & $0.64 \%$ & 7950383 & $0.64 \%$ & $\mathrm{U} 5 \rightarrow \mathrm{U} 4$ & $4.20 \%$ & 8231738 & $4.20 \%$ \\
\hline $\mathrm{Q} 2-2012$ & 8120000 & $2.78 \%$ & $3.04 \%$ & 8139906 & $0.25 \%$ & $\mathrm{U} 4 \rightarrow \mathrm{U} 6$ & $1.12 \%$ & 7988651 & $1.62 \%$ \\
\hline Q3-2012 & 8320000 & $2.46 \%$ & $0.88 \%$ & 8191832 & $1.54 \%$ & $\mathrm{U} 6 \rightarrow \mathrm{U} 5$ & $2.87 \%$ & 8352715 & $0.39 \%$ \\
\hline Q4 - 2012 & 8460000 & $1.68 \%$ & $0.88 \%$ & 8393601 & $0.78 \%$ & U5 $\rightarrow$ U5 & $4.20 \%$ & 8669375 & $2.47 \%$ \\
\hline Q1-2013 & 8430000 & $-0.35 \%$ & $0.64 \%$ & 8513954 & $1.00 \%$ & $\mathrm{U} 5 \rightarrow \mathrm{U} 4$ & $4.20 \%$ & 8815254 & $4.57 \%$ \\
\hline Q2-2013 & 8610000 & $2.14 \%$ & $0.88 \%$ & 8504574 & $1.22 \%$ & $\mathrm{U} 4 \rightarrow \mathrm{U} 5$ & $1.12 \%$ & 8524598 & $0.99 \%$ \\
\hline Q3-2013 & 8820000 & $2.44 \%$ & $0.88 \%$ & 8686166 & $1.52 \%$ & U5 $\rightarrow$ U5 & $4.20 \%$ & 8971553 & $1.72 \%$ \\
\hline Q4-2013 & 8920000 & $1.13 \%$ & $0.64 \%$ & 8876250 & $0.49 \%$ & $\mathrm{U} 5 \rightarrow \mathrm{U} 4$ & $4.20 \%$ & 9190371 & $3.03 \%$ \\
\hline & & & & AFER & $0.78 \%$ & & & & $2.74 \%$ \\
\hline
\end{tabular}

